\title{
COMPARISON STUDY OF "U+L" AND "Y+L" WORKING FACE VENTILATION PATTERNS ON GAS CONTROL IN A HIGHLY GASSY MINE
}

\author{
He Shao, Kai-yan Chen, Hong-mei Zhao, Ming-ming Li
}

Original scientific paper A mine ventilation system is an important component of an underground mining system. We all know that the ventilation system design plays an important role in highly gassy mines, and the ventilation pattern is the primary factor in gob gas control in fully mechanized working faces. Because the gas emission rate is notably large in highly gassy fully mechanized working faces and the $U$ ventilation pattern seriously restricts normal production, a new ventilation pattern is required. This paper uses a gas flow distribution numerical simulation method to analyze the gas controlling effect of $\mathrm{U}+\mathrm{L}$ and $\mathrm{Y}+\mathrm{L}$ patterns. The results indicate that the gas concentration of the $\mathrm{U}+\mathrm{L}$ ventilation pattern is lower than that of $\mathrm{Y}+\mathrm{L}$ pattern in a fully mechanized working face and its upper corner. Furthermore, the main ventilation factors that affect the gas drainage of $\mathrm{U}+\mathrm{L}$ ventilation pattern are optimized through the orthogonal test and fuzzy evaluation method; it effectively reduces the gas concentration of the upper corner and the return airway. After the implementation of the optimal solution of the $\mathrm{U}+\mathrm{L}$ ventilation pattern in No. $32_{2} 12_{(1)}$ working face of Rujigou coal mine of Ningxia Hui Autonomous Region in China, the gas concentration of the upper corner was reduced to $0,6 \%$, which can ensure the normal production of the coal mine.

Keywords: highly gassy; gas controlling; parameters optimization; $U+L$ ventilation pattern

\section{Usporedna analiza modela ventilacije "U+L" i "Y+L" u regulaciji plina na iskopu u rudniku s velikom količinom plina}

Izvorni znanstveni članak

Sustav ventilacije u rudniku važna je sastavnica podzemnog sustava za vađenje rude. Poznato je da je projekt ventilacijskog sustava od velike važnosti u rudnicima s izvanredno velikim količinama plina te je model ventilacije primarni čimbenik u reguliranju plina kod potpuno mehaniziranih iskopa. Budući da je količina ispuštanja plina posebno velika u potpuno mehaniziranim iskopima s krajnje visokim količinama plina te da U model ventilacije ozbiljno ograničava normalnu proizvodnju, potreban je novi model ventilacije. U ovom je radu primijenjena metoda numeričke simulacije distribucije protoka plina $u$ analizi učinka reguliranja plina u modelima $U+L$ i $Y+L$. Rezultati pokazuju da je koncentracija plina u U+L modelu ventilacije niža nego u modelu $\mathrm{Y}+\mathrm{L}$ kod potpuno mehaniziranog iskopa i njegovog gornjeg ugla. Nadalje, glavni čimbenici ventilacije koji utječu na odvod plina kod U+L modela ventilacije optimizirani su ortogonalnim testom i metodom fuzzy evaluacije; tako se učinkovito smanjila koncentracija plina u gornjem uglu i povratnom prolazu za ventilaciju. Nakon implementacije optimalnog rješenja modela ventilacije U+L u iskopu No. $32_{2} 12_{(1)}$ rudnika ugljena Rujigou u autonomnoj pokrajini Ningxia Hui u Kini, koncentracija plina u gornjem uglu smanjena je na 0,6 \%, što može osigurati normalnu proizvodnju ugljenokopa.

Ključne riječi: optimizacija parametara; regulacija plina; $U+L$ model ventilacije; visoko plinovit

\section{Introduction}

A mine ventilation system is an important component of an underground mining system. This system should provide a sufficient quantity of air to the underground mine workings to dilute methane and other contaminants, maintain suitable working environment and prevent accidents from happening [1]. Mine ventilation is also a basic and effective measure to prevent gas accumulation. The $U$ ventilation pattern and $\mathrm{Y}$ ventilation pattern of working faces are very common at present in China. The advantage of the $U$ ventilation pattern is its simple structure and reliable ventilation function; however, the gas concentration of working faces especially in the upper corners and return airway are often overrun as the gas emission rate is larger than ordinary working faces [2]. The $\mathrm{Y}$ ventilation pattern adopts the tail roadway, which can change the airflow direction and alleviate the gas overrun problems [3]. The gas drainage technology and Ventilation Air Methane (VAM) are the main methods to control the gas. To improve the quantities of gas drainage and VAM efficiency in a gassy coal mine, the adjustment of working face ventilation patterns is often used to ensure the safety of coal production.

In tandem with experimental design and studies, researchers have applied the tool of computational fluid dynamics (CFD) to investigate and characterize the underground mine ventilation system [4]. A number of successful cases have been reported. CFD modelling to investigate ventilation airflow [5], methane emission [6], coal spontaneous heating, underground fires $[7,8,9]$ and dust dispersion in underground mines were conducted $[10,11]$. The gob gas distribution law and ventilation parameters of $\mathrm{Y}$ ventilation patterns were analyzed using numerical simulation methods $[12,13]$. The gob gas distribution and migration law of $U$ ventilation pattern were simulated using the finite element numerical simulation by Li Z. X $[14,15]$. In addition, Wang K, et al. used the numerical simulation method to study the gob gas distribution of $\mathrm{J}$ ventilation pattern working faces with reserved tail roadways $[16,17]$. Cheng Y. P. studied the air distribution relationship of $\mathrm{Y}$ ventilation patterns [18], but the VAM efficiency was never discussed. In conclusion, little research has been conducted to study the gas controlling efficiency of different ventilation patterns and the optimization of ventilation parameters.

This paper selects the No. $32_{2} 12_{(1)}$ working face of Rujigou coal mine of Ningxia Hui Autonomous Region in China as the basis, and a numerical simulation method is used to study the gas controlling effect of $\mathrm{U}+\mathrm{L}$ and $\mathrm{Y}+\mathrm{L}$ patterns, respectively. Furthermore, the orthogonal test and fuzzy evaluation method are used to optimize the main ventilation factors that affect the gas drainage of $\mathrm{U}+\mathrm{L}$ ventilation patterns.

\section{General situation of coal mine}

Rujigou coal mine is located in the northern tip of Ningxia Helan Mountains in China. Its coal production capacity is 1,5 million tons per year. No. $32_{2} 12_{(1)}$ fully 
mechanized working face is the first layered working face of No. $322_{2} 12$ area, which excavates the coal of No. $2_{2}^{1}$ coal seam. The maximum relative gas emission rate is $13,15 \mathrm{~m}^{3} / \mathrm{t}$, and the maximum absolute gas emission rate is $22,94 \mathrm{~m}^{3} / \mathrm{min}$. The working face adopts a $\mathrm{U}$ ventilation pattern, which seriously restricts the normal production of the working face as the gas concentration of return airway is higher and the gas concentration of the upper corner is easily overrun. The schematic diagram of the $U$ ventilation pattern in $32_{2} 12_{(1)}$ working face is shown in Fig. 1.

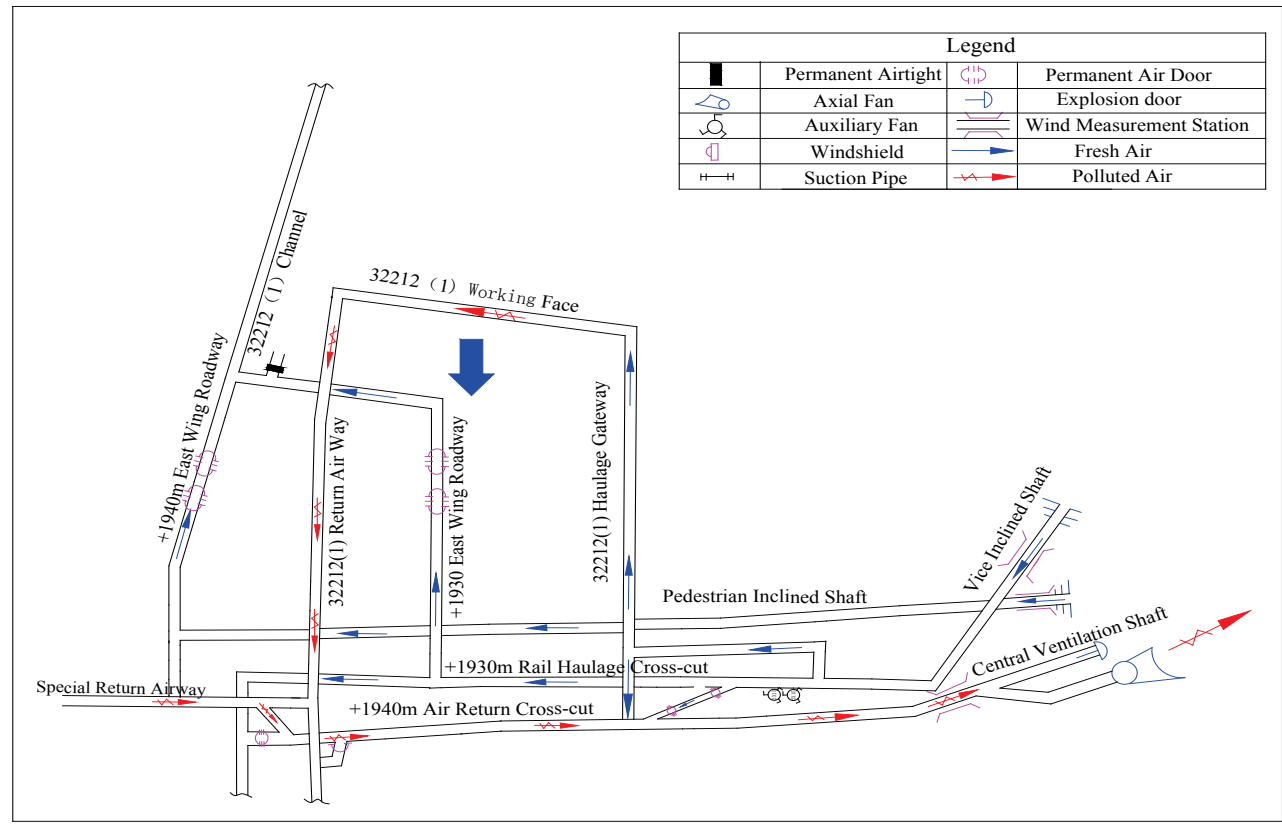

Figure 1 Schematic diagram of the $U$ pattern ventilation mode in $32_{2} 12_{(1)}$ working face

According to the characteristics of high gas emission rate of No. $32_{2} 12_{(1)}$ fully mechanized working face, the gas controlling schemes of "one air intake two air return" $\mathrm{U}+\mathrm{L}$ ventilation pattern and "two air intake one air return"
$\mathrm{Y}+\mathrm{L}$ ventilation pattern are respectively put forward. The numerical simulation parameters of the two schemes are shown in Tab. 1.

Table $1 \mathrm{U}+\mathrm{L}$ and $\mathrm{Y}+\mathrm{L}$ ventilation schemes in $32_{2} 12$ (1) working face

\begin{tabular}{|c|c|c|c|c|c|}
\hline Scheme & $\begin{array}{c}\text { Ventilation } \\
\text { pattern }\end{array}$ & $\begin{array}{c}\text { Air quantity of air } \\
\text { intake roadway } / \mathrm{m}^{3} / \mathrm{min}\end{array}$ & $\begin{array}{c}\text { Air quantity of return } \\
\text { roadway } / \mathrm{m}^{3} / \mathrm{min}\end{array}$ & $\begin{array}{c}\text { Air quantity of tail } \\
\text { roadway } / \mathrm{m}^{3} / \mathrm{min}^{2}\end{array}$ & $\begin{array}{c}\text { Exhaust volume of } \\
\text { installation roadway } \\
/ \mathrm{m}^{3} / \mathrm{min}\end{array}$ \\
\hline Scheme 1 & $\mathrm{U}+\mathrm{L}$ & 2360 & -600 & -1260 \\
\hline Scheme 2 & $\mathrm{Y}+\mathrm{L}$ & 1850 & 600 & -500 \\
\hline
\end{tabular}

\section{Numerical simulation of gas airflow field of $U+L$ and} $Y+L$ working faces

3.1 The establishment of a physical model and meshing of a numerical simulation

The physical model of numerical simulation is established based on the actual geometry of No. $32_{2} 12_{(1)}$ fully mechanized working face. The specific parameters include the following: the cross section of the tail roadway is $2 \times 3 \mathrm{~m}$; the cross-section of gas drainage in the installation roadway is $3 \times 3 \mathrm{~m}$; the cross section of air intake and return roadway is $5 \times 3 \mathrm{~m}$; the length of the working face is $250 \mathrm{~m}$; the volume of gob is $250 \times 150 \times$ $35 \mathrm{~m}$ (wide $\times$ length $\times$ height). The physical model and meshing are shown in Fig. 2.

The stope can be divided into three areas: the working face, the roadway (including air intake and return roadway, L tail roadway and the installation roadway) and the gob. The initial parameters of gob is the porous zone, the other is the fluid type. The meshing spacing is $2 \mathrm{~m}$ in gob and others is $0,5 \mathrm{~m}$. There are approximately 1,5 million grids in this model.

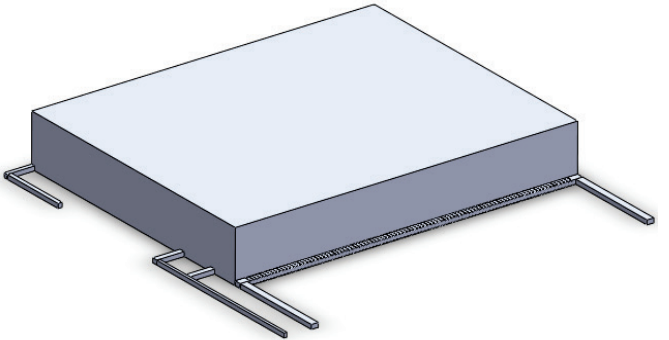

(a) The physical model

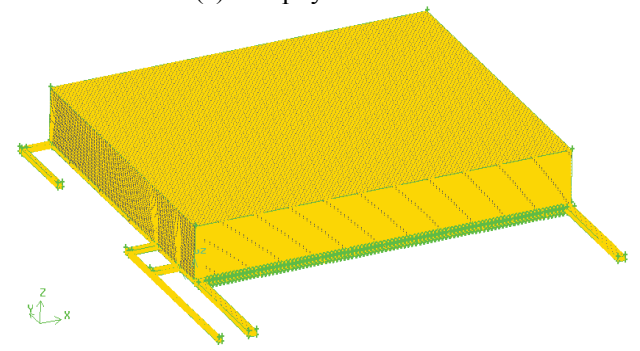

(b) The meshing

Figure 2 The physical model and meshing of No. $32_{2} 12_{(1)}$ fully mechanized working face 


\subsection{Gas mass source terms of working face}

According to actual observation of gas emissions in coal seams and the mining process of No. $322_{2} 12_{(1)}$ working face, the gas mass source terms include the coal wall emission, the gob emission and cutting coal of shearer emission. The gob gas emissions are mainly composed of the wall rock emissions and mining residual coal emissions. After cutting coal, the total gas emission rate of the working face is $21,36 \mathrm{~m}^{3} / \mathrm{min}$. The coal wall emission rate is $7,45 \mathrm{~m}^{3} / \mathrm{min}$, which is $34,88 \%$ of the total amount of emissions, and its mass source term is set at the uniform emission in the $0,3 \mathrm{~m}$ wide from the coal wall. The gob emission rate is $10,11 \mathrm{~m}^{3} / \mathrm{min}$, which is $47,33 \%$ of the total amount of emissions, and it can be divided into two parts; the emission scales are $50 \%$ each. Among them, the mining residual coal emission is set at the uniform emission within the $1 \mathrm{~m}$ width from the floor of the gob; and the wall rock emission is set at the uniform emission out of the $1 \mathrm{~m}$ width from the floor of the gob. The cutting coal of shearer emission rate is 3.8 $\mathrm{m}^{3} / \mathrm{min}$, which is $17,79 \%$ of the total amount emission, and its mass source term is set at the uniform emission in the $0,3 \mathrm{~m}$ wide from the floor of the working face. The gas mass source terms setting is shown in Tab. 2 .

\begin{tabular}{|c|c|c|c|c|}
\hline $\begin{array}{c}\text { Gas emission } \\
\text { area }\end{array}$ & Coal wall & $\begin{array}{c}\text { Cutting } \\
\text { coal of } \\
\text { working } \\
\text { face }\end{array}$ & $\begin{array}{c}\text { Residual } \\
\text { coal of } \\
\text { gob }\end{array}$ & $\begin{array}{l}\text { Wall } \\
\text { rock of } \\
\text { gob }\end{array}$ \\
\hline $\begin{array}{l}\text { Gas emission } \\
\text { rate } / \mathrm{m}^{3} / \mathrm{min}\end{array}$ & 7,45 & 3,8 & 5,055 & 5,055 \\
\hline $\begin{array}{l}\text { Gas emission } \\
\text { volume } / \mathrm{m}^{3}\end{array}$ & 225 & 375 & 37500 & 1275000 \\
\hline $\begin{array}{l}\text { Mass source } \\
/ \mathrm{kg} /\left(\mathrm{m}^{3} \cdot \mathrm{s}\right)\end{array}$ & $4,26 \mathrm{E}-04$ & $1,30 \mathrm{E}-04$ & $1,74 \mathrm{E}-06$ & $5,10 \mathrm{E}-08$ \\
\hline
\end{tabular}

\subsection{Boundary conditions}

The boundary conditions of Scheme 1 and Scheme 2 are as follows:

Scheme 1: the entry point of the air intake roadway is VELOCITY INLET; the exit point of the return airway, L type tail roadway and installation roadway is OUTFLOW, and the proportion of these three exit points are $25,4 \%$, $53,4 \%$ and $21,2 \%$, respectively. The air velocity of intake airway is $2,62 \mathrm{~m} / \mathrm{s}$. The air volume fraction of $\mathrm{CH}_{4}$ is $0,1 \%$ and $\mathrm{O}_{2}$ is $20 \%$ in the entry point, and the remainder is $\mathrm{N}_{2}$.

Scheme 2: the entry point of the air intake roadway and return airway are VELOCITY INLET, and the air velocity of these entry points are $2,06 \mathrm{~m} / \mathrm{s}$ and $0,67 \mathrm{~m} / \mathrm{s}$; the exit point of $\mathrm{L}$ type tail roadway and installation roadway are OUTFLOW, and the proportion of these exit points is $29,6 \%$ and $20,4 \%$, respectively. The air volume fraction of $\mathrm{CH}_{4}$ is $0,1 \%$ and of $\mathrm{O}_{2}$ is $20 \%$ in the entry point, and the remainder is $\mathrm{N}_{2}$.

\subsection{Numerical simulation analysis of different ventilation patterns}

The air velocity vectors of Scheme 1 and Scheme 2 are shown in Fig. 3, the air velocity contour is shown in
Fig. 4, and the stope gas distribution contour is shown in Fig. 5.

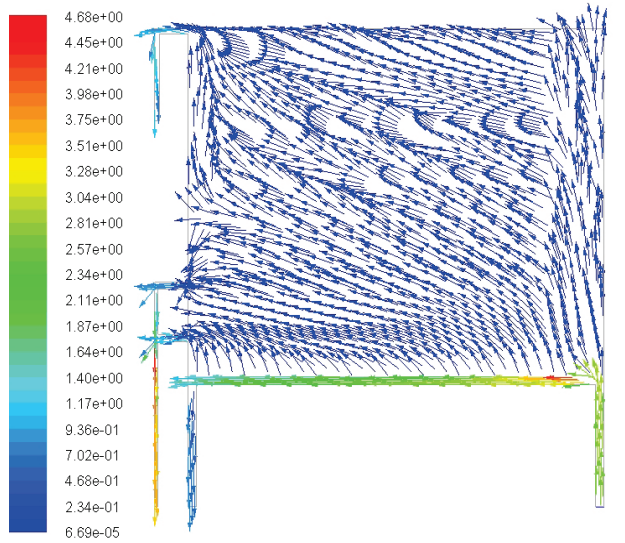

(a) Scheme 1

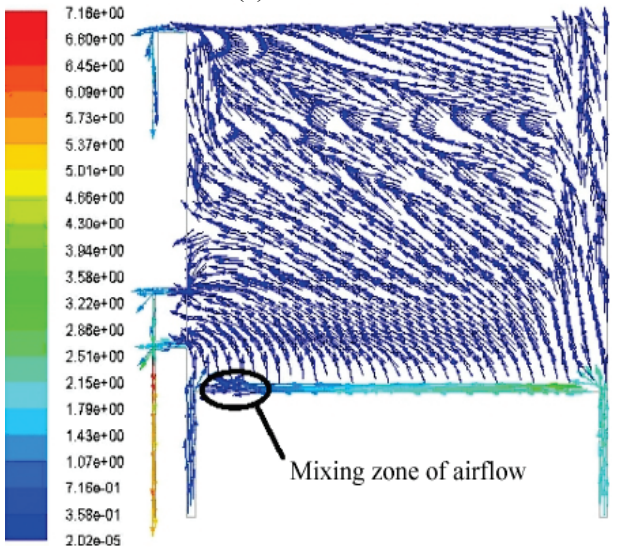

(b) Scheme 2

Figure 3 Velocity vectors of Scheme 1 and Scheme 2

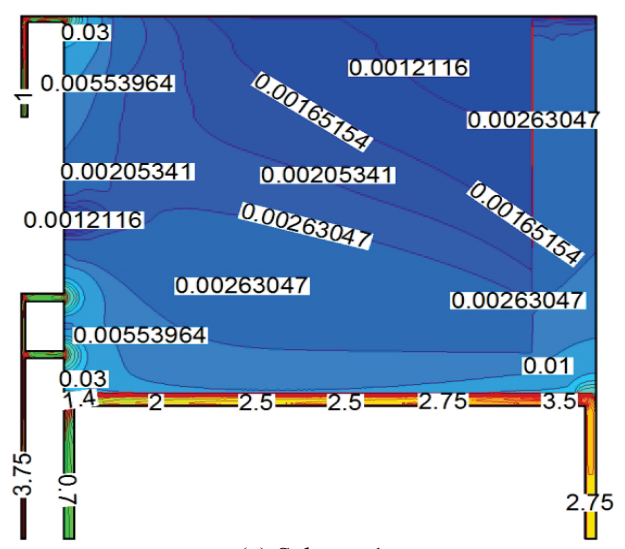

(a) Scheme 1

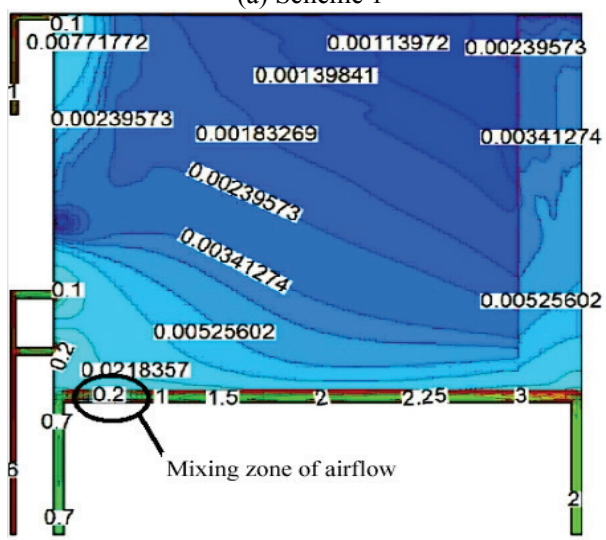

(b) Scheme 2

Figure 4 Air velocity contours of Scheme 1 and Scheme 2 
From Fig. 3(a) and Fig. 4(a), the characteristic of airflow field is that the fresh air flows to the entering point of the working face through the intake airway, then most of the air flows to the return airway through the working face, and parts of the air leak into the gob (the maximum amount of air leakage is in the return airway side). Most of the air leakage from the working face to the gob enters the return airway of the mining area through the L type tail roadway. However, the air quantity of the installation roadway is relatively small.

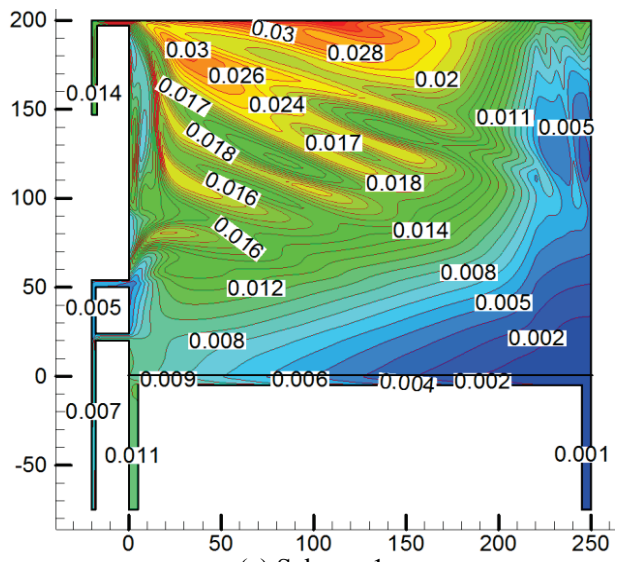

(a) Scheme 1

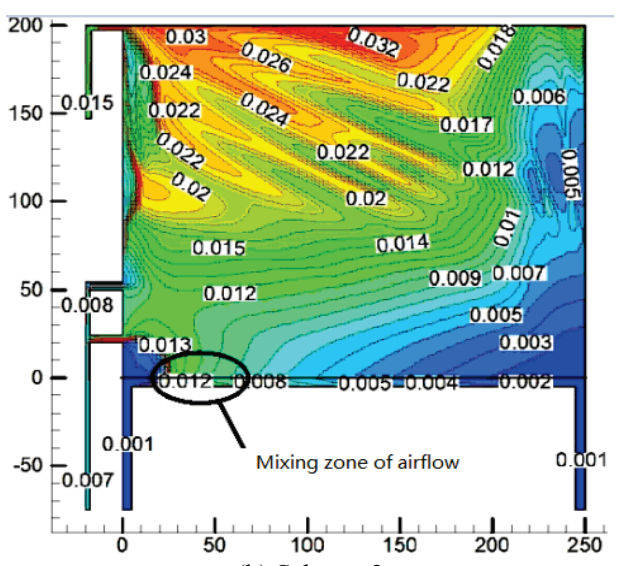

(b) Scheme 2

Figure 5 Gas distribution contour of Scheme 1 and Scheme $2(z=1,5 \mathrm{~m})$

From Fig. 5(a), the main function of the L type tail roadway and the installation roadway is to drain the methane in the gob. At the larger pumping rate, most of the gas concentration in the gob close to the working face is relatively low. The numerical simulation shows that the gas concentration of the L type tail roadway and back of the gob is relatively low, and the gas concentration in L type tail roadway is approximately $0,7 \%$, the installation roadway is $1,2 \%$ to $1,5 \%$, and the working face is below $1 \%$.

From Fig. 3(b) and Fig. 4(b), because both the original intake airway and the return airway are changed into the air intake roadway, a $20 \mathrm{~m}$ range airflow mixing zone appears approximately $50 \mathrm{~m}$ away from the return airway (Fig. 3(b)). The air velocity is reduced below 0,2 $\mathrm{m} / \mathrm{s}$ in the mixing zone. Some of the downward airflow mixes with the upward airflow in the working face, so the gas concentration reaches the maximum value in the working face as the lower air velocity and the accumulation of coal wall gas emission.
Because the gas emission in the coal wall is approximately $7,45 \mathrm{~m}^{3} / \mathrm{min}$ of No. $32_{2} 12_{(1)}$ working face, which represents $34,88 \%$ of the stope emission, the average gas concentration increases approximately $1,2 \div$ $1,6 \%$ in the mixing zone, and the highest gas concentration increases up to $1,8 \%$ (Fig. 5(b)).

From the numerical simulation, we can conclude:

(1) The gas drainage in the back of the working face can reduce the overall amount of gas in the gob, so the gas drainage is essential.

(2) According to the comparison of numerical simulation experiment of Scheme 1 and Scheme 2 under the same gas emissions condition, it can be observed that the gas concentration of the upper corner is approximately $0,9 \%$ in Scheme 1; however, the gas concentration of the airflow mixing zone is $1,2 \div 1,8 \%$ in Scheme 2 . Therefore, the "one air intake two air return" U+L ventilation pattern is more optimal than the "two air intake one air return" $\mathrm{Y}+\mathrm{L}$ ventilation pattern in No. $32{ }_{2} 12_{(1)}$ working face.

\section{The orthogonal and simulation test of optimal ventilation parameters of the working face with the $U+L$ ventilation pattern \\ 4.1 Numerical simulation of stope gas distribution in different factor levels of the orthogonal test}

The minimum air quantity of No. $32_{2} 12_{(1)}$ working face is $1540 \mathrm{~m}^{3} / \mathrm{min}$ during the whole mining process; the minimum air quantity of the $\mathrm{L}$ type tail roadway is 320 $\mathrm{m}^{3} / \mathrm{min}$; the maximum supply air quantity is $3100 \mathrm{~m}^{3} / \mathrm{min}$. According to the actual situation of ventilation capacity of No. $32_{2} 12_{(1)}$ working face, the combination method of the orthogonal test and fuzzy optimization evaluation method is put forward to determine the optimal ventilation parameters scheme. From the air quantity conservation law, the return air quantity is calculated by the intake air quantity, air quantity of the L type tail roadway and drainage quantity of back gob, so there are 3 factors in the orthogonal test, including the intake air quantity A, air quantity of L type tail roadway B and drainage quantity of back gob C. Using the orthogonal test design, the following 4 groups of factors are set to determine the different levels and tests. Tab. 3 illustrates the factor levels of the orthogonal test.

Using the orthogonal table $\mathrm{L}_{16}\left(4^{5}\right), 16$ representative schemes are selected from $4^{3}$ test schemes (Tab. 4 ).

Table 3 Factor levels of orthogonal test

\begin{tabular}{|c|c|c|c|c|}
\hline \multirow{2}{*}{ Factors } & \multicolumn{4}{|c|}{ Levels } \\
\cline { 2 - 5 } & 1 & 2 & 3 & 4 \\
\hline Intake air quantity $\mathrm{A} / \mathrm{m}^{3} / \mathrm{min}$ & 2500 & 2700 & 2900 & 3100 \\
\hline $\begin{array}{c}\text { Return air quantity of } \\
\text { tail roadway B } / \mathrm{m}^{3} / \mathrm{min}\end{array}$ & 300 & 600 & 900 & 1200 \\
\hline $\begin{array}{c}\text { Drainage quantity of } \\
\text { installation roadway } \mathrm{C} / \mathrm{m}^{3} / \mathrm{min}\end{array}$ & 300 & 80 & 150 & 200 \\
\hline
\end{tabular}

After using the fluent numerical simulation software, the results of 16 schemes that were determined by the orthogonal test are shown in Fig. 6. 
Table 4 Factor levels of orthogonal test

\begin{tabular}{|c|c|c|c|}
\hline $\begin{array}{c}\text { E } \\
\text { ¿ }\end{array}$ & $\begin{array}{c}\text { Intake air } \\
\text { quantity A / } \\
\mathrm{m}^{3} / \mathrm{min}\end{array}$ & $\begin{array}{c}\text { Return air } \\
\text { quantity of tail } \\
\text { roadway B } \\
\mathrm{m}^{3} / \mathrm{min}\end{array}$ & $\begin{array}{c}\text { Drainage quantity } \\
\text { of installation } \\
\text { roadway C / } \\
\mathrm{m}^{3} / \mathrm{min}\end{array}$ \\
\hline 1 & $1(2500)$ & $1(300)$ & $1(300)$ \\
\hline 2 & $1(2500)$ & $2(600)$ & $2(80)$ \\
\hline 3 & $1(2500)$ & $3(900)$ & $3(150)$ \\
\hline 4 & $1(2500)$ & $4(1200)$ & $4(200)$ \\
\hline 5 & $2(2700)$ & $1(300)$ & $2(80)$ \\
\hline 6 & $2(2700)$ & $2(600)$ & $1(300)$ \\
\hline 7 & $2(2700)$ & $3(900)$ & $4(200)$ \\
\hline 8 & $2(2700)$ & $4(1200)$ & $3(150)$ \\
\hline 9 & $3(2900)$ & $1(300)$ & $3(150)$ \\
\hline 10 & $3(2900)$ & $2(600)$ & $4(200)$ \\
\hline 11 & $3(2900)$ & $3(900)$ & $1(300)$ \\
\hline 12 & $3(2900)$ & $4(1200)$ & $2(80)$ \\
\hline 13 & $4(3100)$ & $1(300)$ & $4(200)$ \\
\hline 14 & $4(3100)$ & $2(600)$ & $3(150)$ \\
\hline 15 & $4(3100)$ & $3(900)$ & $2(80)$ \\
\hline 16 & $4(3100)$ & $4(1200)$ & $1(300)$ \\
\hline
\end{tabular}

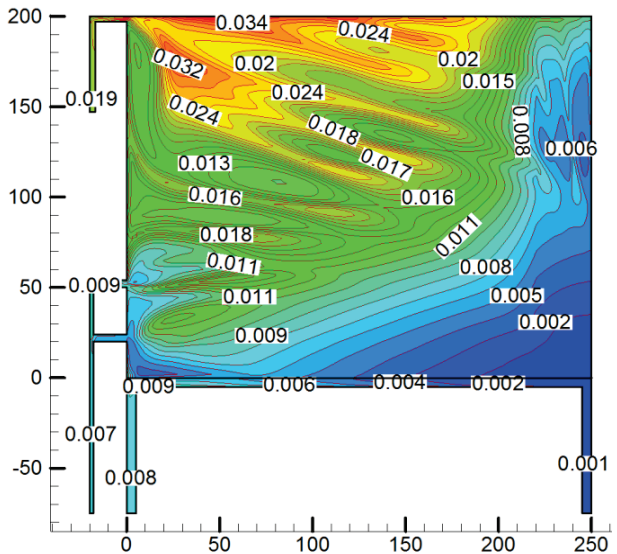

Figure 6(a) Scheme 1

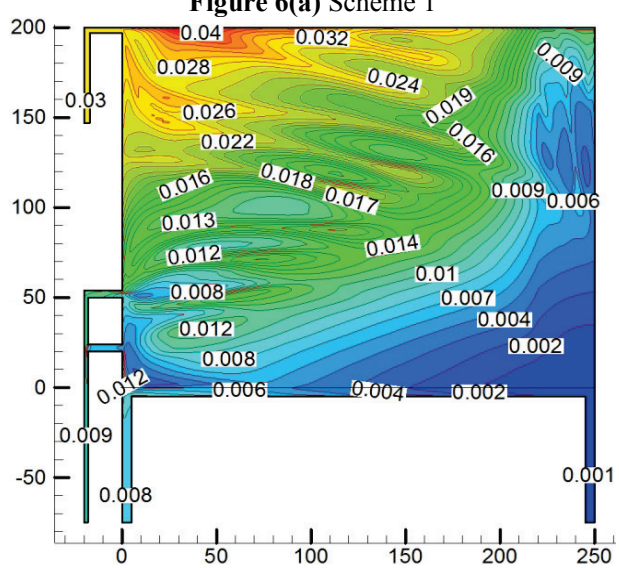

Figure 6(b) Scheme 2

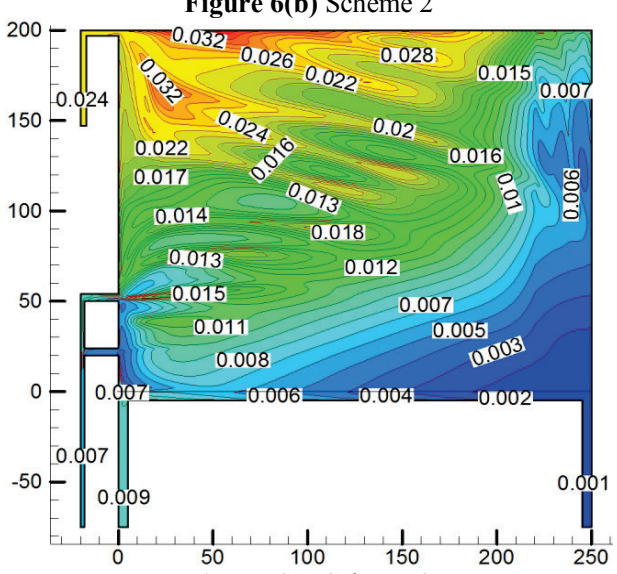

Figure 6(c) Scheme 3

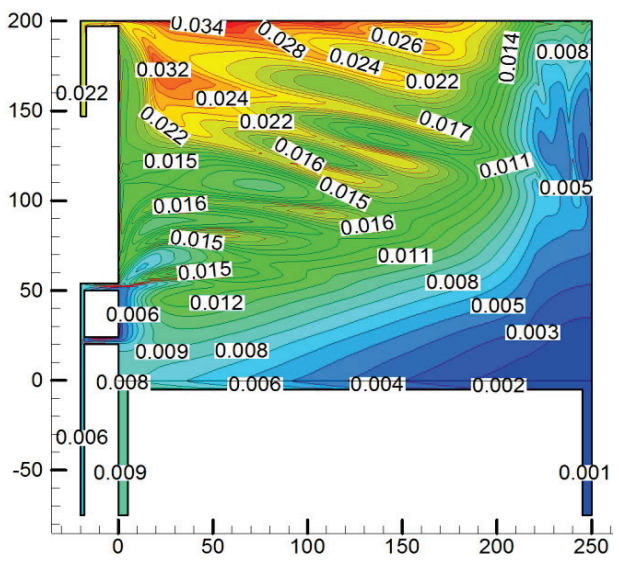

Figure 6(d) Scheme 4

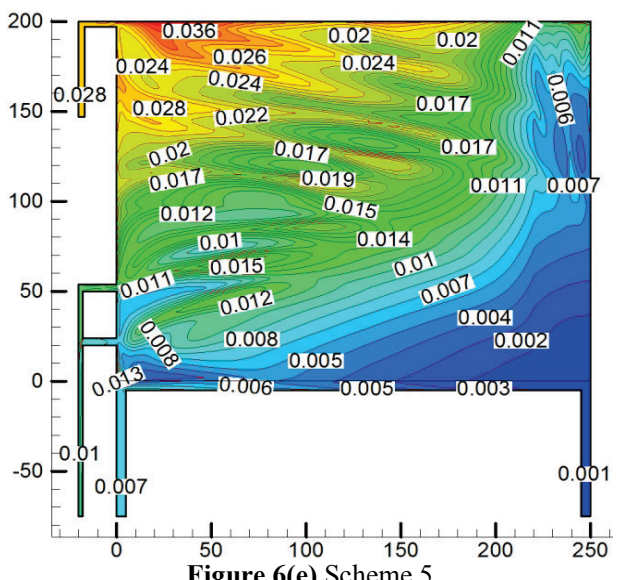

Figure 6(e) Scheme 5

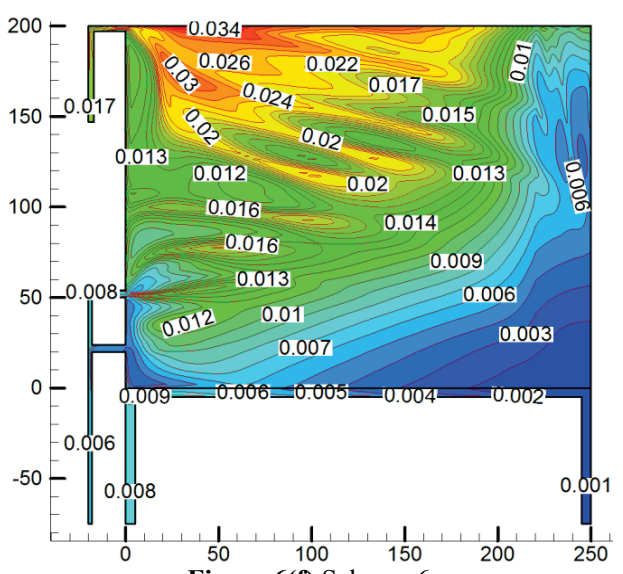

Figure 6(f) Scheme 6

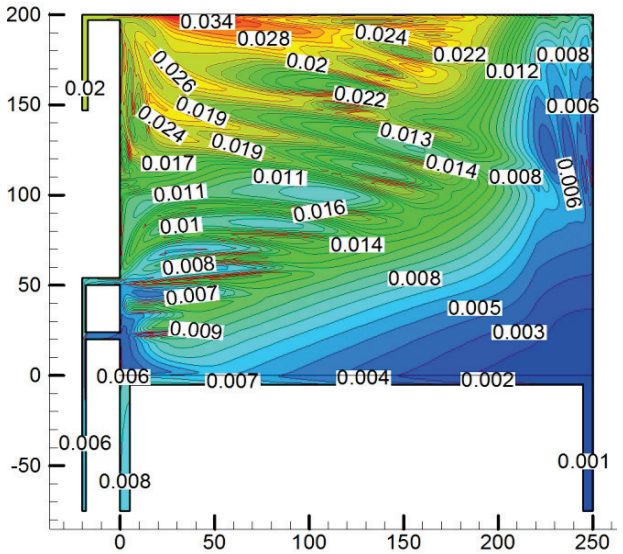

Figure 6(g) Scheme 7 


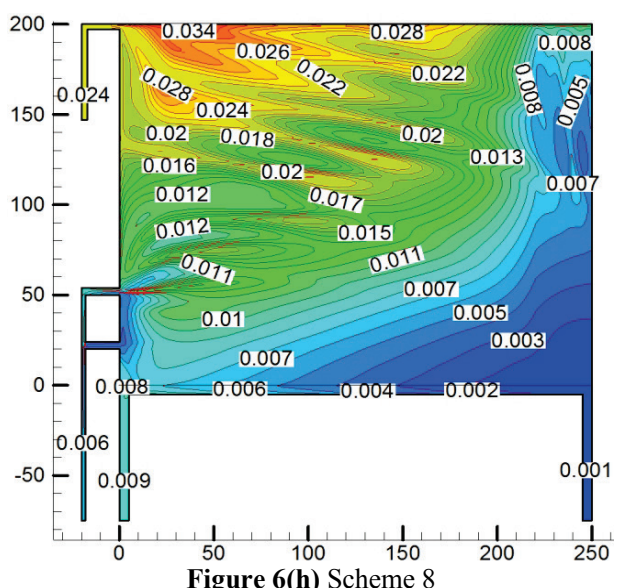

Figure 6(h) Scheme 8

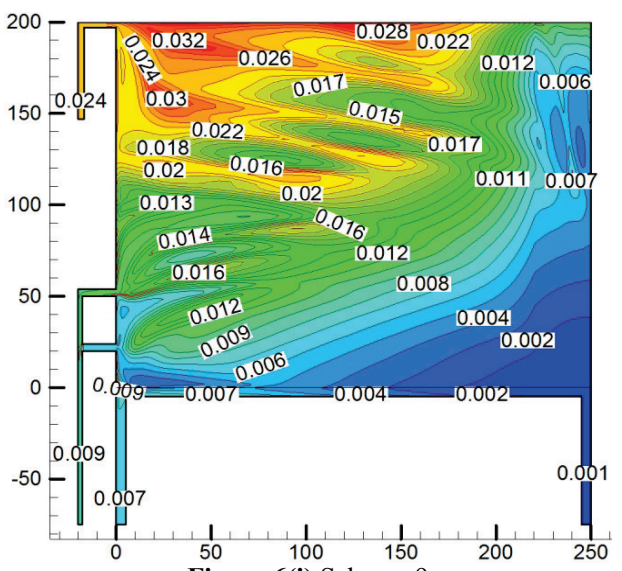

Figure 6(i) Scheme 9

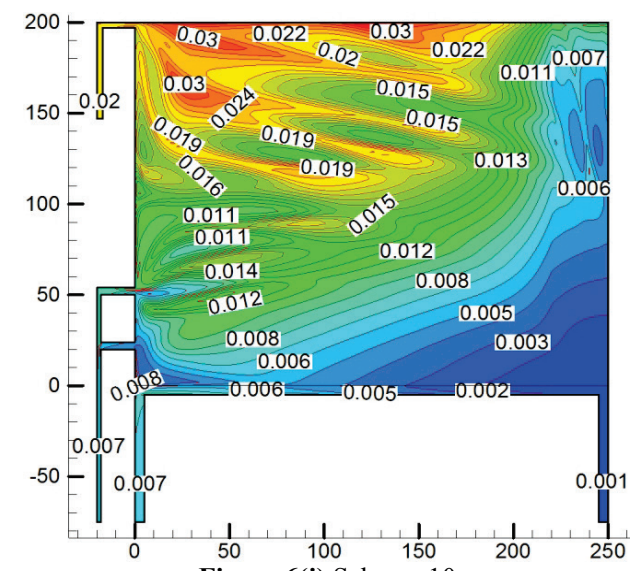

Figure 6(j) Scheme 10

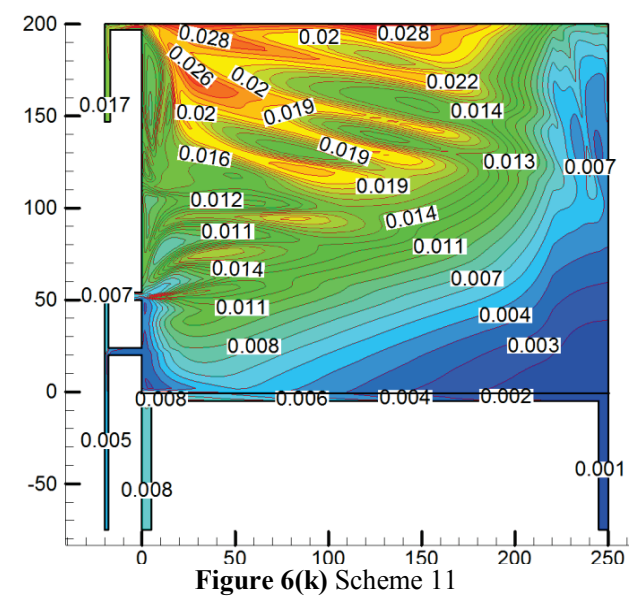

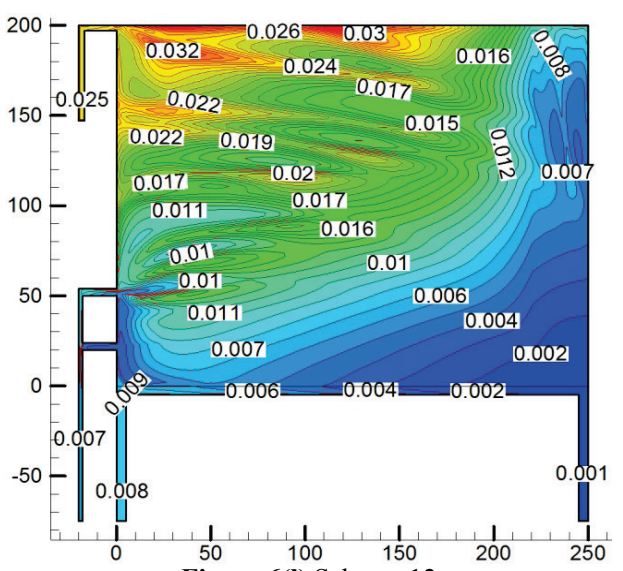

Figure 6(l) Scheme 12

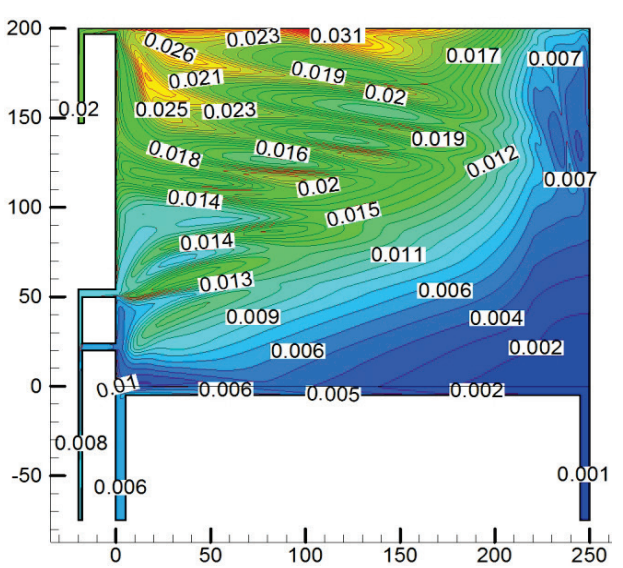

Figure 6(m) Scheme 13

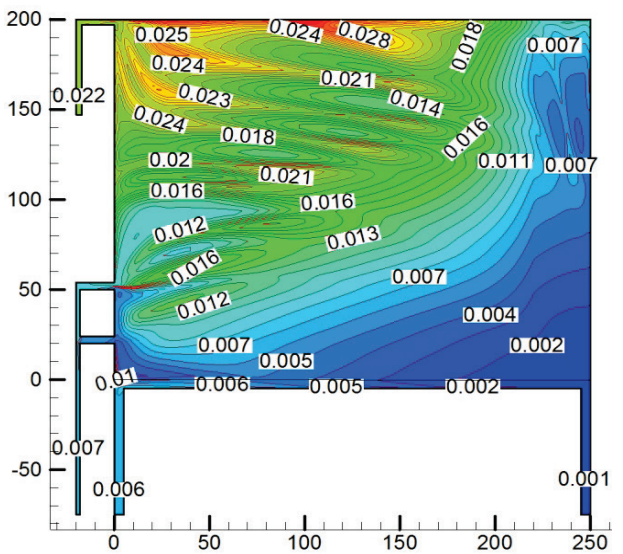

Figure 6(n) Scheme 14

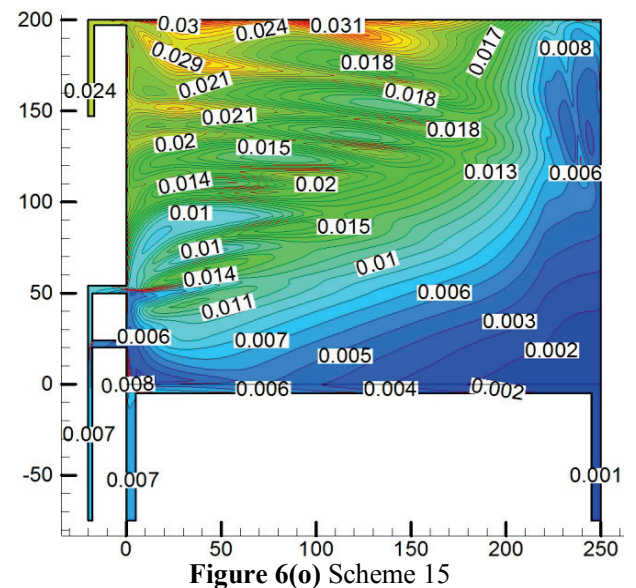

Figure 6(0) Scheme 15 


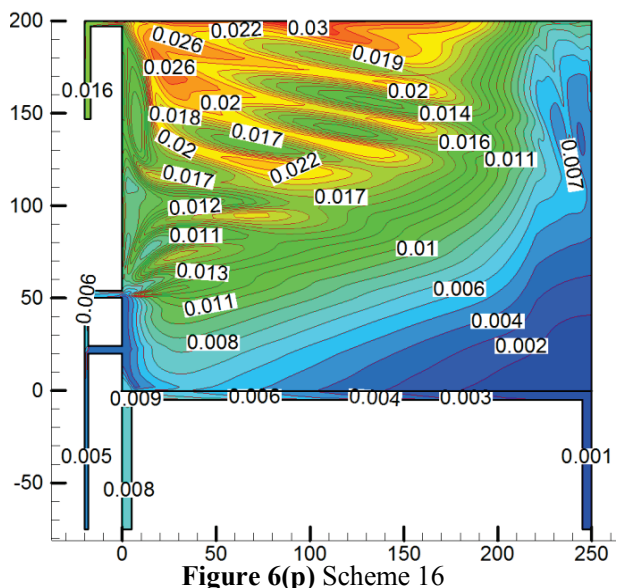

Figure 6 Numerical simulation results of orthogonal test schemes $(z=1,5 \mathrm{~m})$

\subsection{Fuzzy optimization of orthogonal test schemes}

Based on the fuzzy math and the principle of fuzzy relations synthesis, fuzzy optimization is an evaluation method that quantifies some of the factors and evaluates the multiple factors quantitatively.

\section{(1) Determining the index set of fuzzy optimization}

\section{evaluation}

According to the orthogonal test schemes (Tab. 5), the factors of intake air quantity $\left(u_{1}\right)$, the maximum gas concentration $\left(u_{2}\right)$, the average gas concentration of return airway $\left(u_{3}\right)$, the average gas concentration of the $\mathrm{L}$ type tail roadway $\left(u_{4}\right)$ and the drainage gas concentration of installation roadway $\left(u_{5}\right)$ are selected as the evaluating indices for orthogonal fuzzy optimization evaluation. Let the index set $U=\left(u_{1}, u_{2}, u_{3}, u_{4}, u_{5}\right)$. Among them, the indexes of $u_{1}, u_{2}, u_{3}$ and $u_{4}$ are cost-based indicators, so the smaller the better; because the gas drainage pipeline is used in the installation roadway, there is no gas overrun risk and the higher gas concentration is propitious for the gas utilization, so $u_{5}$ is the benefit indicator, the bigger the better. Therefore, the maximum gas concentration represents the maximum gas concentration point in the working face. Fig. 7 illustrates the enlarged drawing of stope gas simulation result of Scheme 1 in the return end of the working face. The maximum gas concentration is approximately $0,8 \%$ in the upper corner of the working face, and the maximum gas concentration reaches $0,9 \%$ in the coal wall of the return end. Therefore, the evaluating index of maximum gas concentration of the working face is $0,9 \%$.

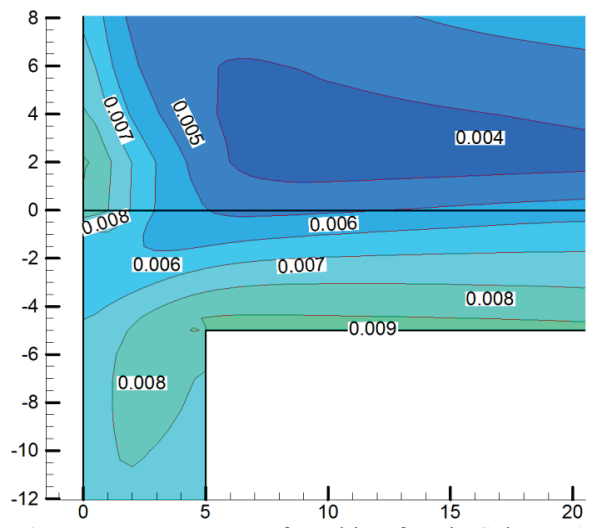

Figure7 Upper corner of working face in Scheme 1

Table 5 Index values of fuzzy optimization in $\mathrm{U}+\mathrm{L}$ ventilation pattern

\begin{tabular}{|c|c|c|c|c|c|}
\hline 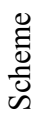 & $\begin{array}{l}\text { The intake } \\
\text { air quantity } \\
/ \mathrm{m}^{3} / \mathrm{min}\end{array}$ & $\begin{array}{c}\text { The maximum gas } \\
\text { concentration in working } \\
\text { face } / \%\end{array}$ & $\begin{array}{c}\text { The average gas } \\
\text { concentration of return } \\
\text { airway } / \%\end{array}$ & $\begin{array}{c}\text { The average gas } \\
\text { concentration of } L \text { type tail } \\
\text { roadway / } \%\end{array}$ & $\begin{array}{c}\text { The drainage gas } \\
\text { concentration of installation } \\
\text { roadway / } \%\end{array}$ \\
\hline 1 & 2500 & 0,938 & 0,759 & 0,736 & 1,854 \\
\hline 2 & 2500 & 1,217 & 0,786 & 0,936 & 2,947 \\
\hline 3 & 2500 & 0,971 & 0,855 & 0,682 & 2,467 \\
\hline 4 & 2500 & 1,010 & 0,927 & 0,641 & 2,157 \\
\hline 5 & 2700 & 1,381 & 0,741 & 1,007 & 2,817 \\
\hline 6 & 2700 & 0,912 & 0,752 & 0,614 & 1,750 \\
\hline 7 & 2700 & 0,931 & 0,796 & 0,614 & 2,099 \\
\hline 8 & 2700 & 0,938 & 0,856 & 0,619 & 2,317 \\
\hline 9 & 2900 & 1,041 & 0,676 & 0,876 & 2,312 \\
\hline 10 & 2900 & 0,885 & 0,688 & 0,684 & 2,061 \\
\hline 11 & 2900 & 0,880 & 0,757 & 0,531 & 1,674 \\
\hline 12 & 2900 & 0,872 & 0,776 & 0,676 & 2,500 \\
\hline 13 & 3100 & 0,975 & 0,633 & 0,805 & 2,006 \\
\hline 14 & 3100 & 0,956 & 0,650 & 0,727 & 2,180 \\
\hline 15 & 3100 & 0,859 & 0,676 & 0,736 & 2,432 \\
\hline 16 & 3100 & 0,833 & 0,768 & 0,478 & 1,623 \\
\hline
\end{tabular}

\section{(2) Determining the weight set of the fuzzy optimization evaluation}

In the above 5 evaluation indexes, $u_{2}, u_{3}$ and $u_{4}$ are the safety evolution index, and it easily causes an accident if these 3 indexes are overrun. Let $z_{2}=z_{3}=0,3$. Furthermore, as the gas concentration of the $\mathrm{L}$ type tail roadway is below $1,5 \%$, and it is difficult to exceed the management concentration of gas tail roadway $2,5 \%$, so $z_{4}=0,2$. Because $u_{1}$ and $u_{5}$ are economic indicators, they only reflect the ventilation economy and gas drainage efficiency in the capabilities of ventilation and gas drainage, let $z_{1}=z_{5}=0,1$. Therefore, the weight set of the 5 evaluation indexes is:

$Z=\left(z_{1}, z_{2}, z_{3}, z_{4}, z_{5}\right)^{\mathrm{T}}=(0.1,0.3,0.3,0.2,0.1)^{\mathrm{T}}$. 


\section{(3) Mathematical model of fuzzy optimization}

Using a fuzzy optimization analysis method to determine the optimal scheme of $\mathrm{U}+\mathrm{L}$ ventilation pattern, the optimal fuzzy partition matrix element is calculated as

$$
u_{1 j}=\left(1+\frac{\sum_{i=1}^{m}\left(z_{i}\left(g_{i}-r_{i j}\right)\right)^{2}}{\sum_{i=1}^{m}\left(z_{i}\left(r_{i j}-b_{i}\right)\right)^{2}}\right)^{-1}
$$

where $u_{1 j}$ is the standard matrix element of master scheme $r_{i j}$ is the membership degree of Scheme $j$ to evaluation index $i ; n$ is the number of schemes; $m$ is the number of fuzzy evaluation indexes; $g_{i}$ is the maximum value of corresponding membership degree of $n$ schemes; and $b_{i}$ is the minimum value of corresponding membership degree of $n$ schemes.

\section{(4) Analysis and evaluation of fuzzy optimization of orthogonal test}

From the numerical simulation results of the orthogonal test, the index values of the fuzzy optimization evaluation schemes are extracted in Tab. 5 .

The evaluation results of fuzzy optimization in $\mathrm{U}+\mathrm{L}$ ventilation pattern are calculated by the fuzzy optimization theory (Tab. 6).

Table 6 Evaluation results of fuzzy optimization in $\mathrm{U}+\mathrm{L}$ ventilation

\begin{tabular}{|c|c|c|c|}
\hline$\frac{\mathscr{\Xi}}{\stackrel{0}{0}}$ & $\begin{array}{l}\text { The optimal fuzzy } \\
\text { partition matrix element }\end{array}$ & $\frac{\mathscr{\Xi}}{\stackrel{\Xi}{0}}$ & $\begin{array}{l}\text { The optimal fuzzy } \\
\text { partition matrix element }\end{array}$ \\
\hline 1 & 0,7509 & 9 & 0,7064 \\
\hline 2 & 0,3343 & 10 & 0,8881 \\
\hline 3 & 0,5692 & 11 & 0,8186 \\
\hline 4 & 0,4029 & 12 & 0,7882 \\
\hline 5 & 0,2532 & 13 & 0,8006 \\
\hline 6 & 0,8134 & 14 & 0,8446 \\
\hline 7 & 0,7348 & 15 & 0,8746 \\
\hline 8 & 0,6021 & 16 & 0,8004 \\
\hline
\end{tabular}

\subsection{Analysis of the orthogonal test result of stope gas control using the $\mathrm{U}+\mathrm{L}$ ventilation pattern}

Using a fuzzy optimization evaluation method, the above 5 factors are summed up as one index which is the optimal fuzzy partition matrix element. Bringing it into the orthogonal table, the results of the orthogonal test are shown in Tab. 7.

In Tab. $7, \mathrm{I}_{j}, \mathrm{II}_{j}, \mathrm{III}_{j}$ and $\mathrm{IV}_{j}$ represent the sum of the optimal fuzzy partition matrix element corresponding to the No. $j$ column of Level 1, 2, 3 and 4, and the value of $\mathrm{I}_{j}, \quad \mathrm{II}_{j}, \quad \mathrm{III}_{j}$ and $\mathrm{IV}_{j}$ represent the advantage and disadvantage of Level 1, 2, 3 and 4, the larger value being the optima of level. Because IVA>IIIA>IIA>IA, Level 4 is the optimal intake air quantity. Likewise IIIB $>$ IIB $>$ IVB $>$ IB means that Level 3 is the optimal return air quantity of the $\mathrm{L}$ tail roadway; IC $>$ IVC $>$ IIIC $>$ IIC means that Level 1 is the optimal drainage quantity of the installation roadway. Therefore, $\mathrm{A} 4 \mathrm{~B} 3 \mathrm{C} 1$ is the optimal test, the intake air quantity is 3100 $\mathrm{m}^{3} / \mathrm{min}$, the return air quantity is $1900 \mathrm{~m}^{3} / \mathrm{min}$, the return air quantity of the L tail roadway is $900 \mathrm{~m}^{3} / \mathrm{min}$, and the drainage quantity of the back gob is $300 \mathrm{~m}^{3} / \mathrm{min}$.

\begin{tabular}{|c|c|c|c|c|}
\hline Test & $\begin{array}{c}\text { Intake air } \\
\text { quantity } \\
\mathrm{A} / \\
\mathrm{m}^{3} / \mathrm{min}\end{array}$ & $\begin{array}{c}\text { Return air } \\
\text { quantity of } \\
\text { tail } \\
\text { roadway B } \\
/ \mathrm{m}^{3} / \mathrm{min}\end{array}$ & $\begin{array}{l}\text { Drainage } \\
\text { quantity of } \\
\text { installation } \\
\text { roadway C } \\
/ \mathrm{m}^{3} / \mathrm{min} \\
\end{array}$ & $\begin{array}{l}\text { The optimal } \\
\text { fuzzy } \\
\text { partition } \\
\text { matrix } \\
\text { element }\end{array}$ \\
\hline 1 & $1(2500)$ & $1(300)$ & $1(300)$ & 0,7509 \\
\hline 2 & $1(2500)$ & $2(600)$ & $2(80)$ & 0,3343 \\
\hline 3 & $1(2500)$ & $3(900)$ & $3(150)$ & 0,5692 \\
\hline 4 & $1(2500)$ & $4(1200)$ & $4(200)$ & 0,4029 \\
\hline 5 & $2(2700)$ & $1(300)$ & $2(80)$ & 0,2532 \\
\hline 6 & $2(2700)$ & $2(600)$ & $1(300)$ & 0,8134 \\
\hline 7 & $2(2700)$ & $3(900)$ & $4(200)$ & 0,7348 \\
\hline 8 & $2(2700)$ & $4(1200)$ & $3(150)$ & 0,6021 \\
\hline 9 & $3(2900)$ & $1(300)$ & $3(150)$ & 0,7064 \\
\hline 10 & $3(2900)$ & $2(600)$ & $4(200)$ & 0,8881 \\
\hline 11 & $3(2900)$ & $3(900)$ & $1(300)$ & 0,8186 \\
\hline 12 & $3(2900)$ & $4(1200)$ & $2(80)$ & 0,7882 \\
\hline 13 & $4(3100)$ & $1(300)$ & $4(200)$ & 0,8006 \\
\hline 14 & $4(3100)$ & $2(600)$ & $3(150)$ & 0,8446 \\
\hline 15 & $4(3100)$ & $3(900)$ & $2(80)$ & 0,8746 \\
\hline 16 & $4(3100)$ & $4(1200)$ & $1(300)$ & 0,8004 \\
\hline $\mathrm{I}_{j}$ & 2,0572 & 2,5110 & 3,1833 & \\
\hline $\mathrm{II}_{j}$ & 2,4035 & 2,8803 & 2,2502 & \\
\hline $\mathrm{III}_{j}$ & 3,2012 & 2,9972 & 2,7223 & \\
\hline $\mathrm{IV}_{j}$ & 3,3202 & 2,5936 & 2,8263 & \\
\hline $\begin{array}{c}\text { Optimal } \\
\text { level }\end{array}$ & $\mathrm{A}_{4}$ & $\mathrm{~B}_{3}$ & $\mathrm{C}_{1}$ & \\
\hline $\begin{array}{l}\text { Optimal } \\
\text { group }\end{array}$ & \multicolumn{4}{|c|}{$\mathrm{A}_{4} \mathrm{~B}_{3} \mathrm{C}_{1}$} \\
\hline
\end{tabular}

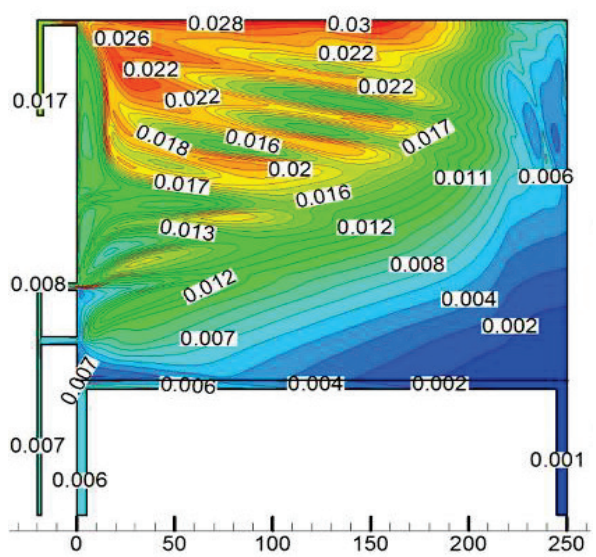

Figure 8 Numerical simulation results of the optimum scheme $(z=1,5 \mathrm{~m})$

Using the $\mathrm{U}+\mathrm{L}$ ventilation pattern, the simulation result of stope gas distribution field of the optimist test $\mathrm{A} 4 \mathrm{~B} 3 \mathrm{C} 1$ is shown in Fig. 8. After the ventilation parameter optimization, the gas concentration is obviously decreased, the gas concentration in upper corner is approximately $0,7 \div 0,72 \%$, the return airway is approximately $0,6 \div 0,65 \%$, the $\mathrm{L}$ tail roadway is approximately $0,6 \div 0,7 \%$, and the drainage gas concentration of the installation roadway is approximately $1,4 \div 1,7 \%$. 


\subsection{The effect of the orthogonal test}

Fig. 9 illustrates the schematic diagram of $\mathrm{U}+\mathrm{L}$ ventilation mode in $32{ }_{2} 12_{(1)}$ working face after the implementation of the optimal scheme.

According to the "Safety Regulations in Coal Mine" of China, mine production must be stopped when the gas concentration of return airway and working face is higher than $1,0 \%$. Before adopting the $\mathrm{U}+\mathrm{L}$ ventilation pattern, the gas concentration of the return airway and working face in No. $32_{2} 12_{(1)}$ working face usually overran and was up to $1,0 \%$. To examine the gas control efficiency after the implementation of $\mathrm{U}+\mathrm{L}$ ventilation type in No. $32_{2} 12_{(1)}$ working face, we gather and analyze the gas concentration of the working face (T2), return airway (T1) and upper corner (T0) with the working face excavation. The measuring points are set as shown in Fig. 10 and the gas concentration of each measuring point is shown in Fig. 11.

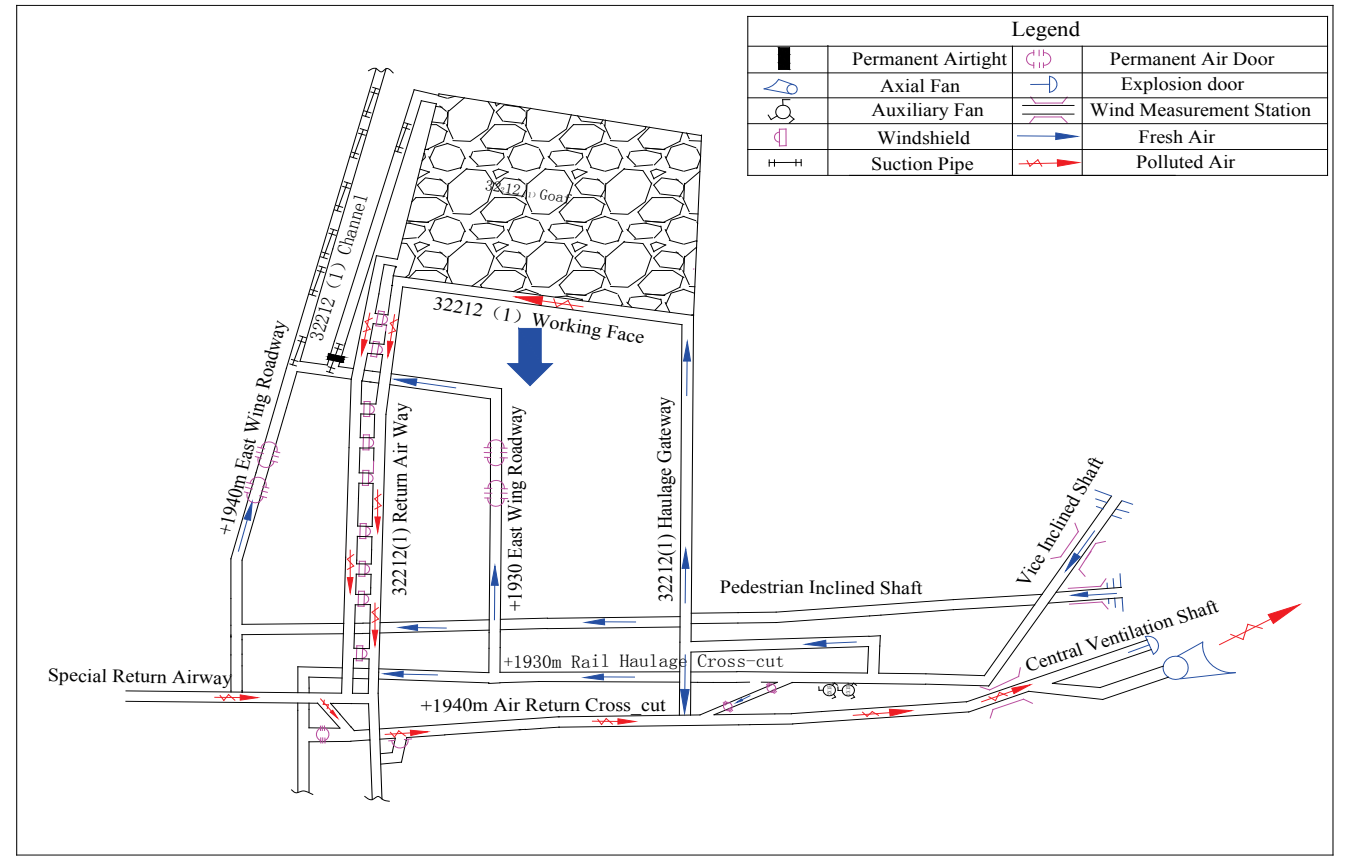

Figure 9 Schematic diagram of $U+L$ ventilation mode in $32_{2} 12_{(1)}$ working face after adopting the optimal scheme

return airflow roadway

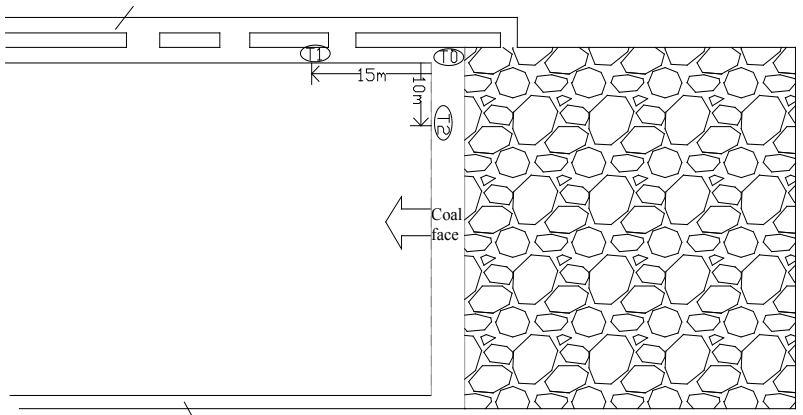

intake airflow roadway

Figure 10 Gas measuring points set in the No. $32_{2} 12_{(1)}$ working face

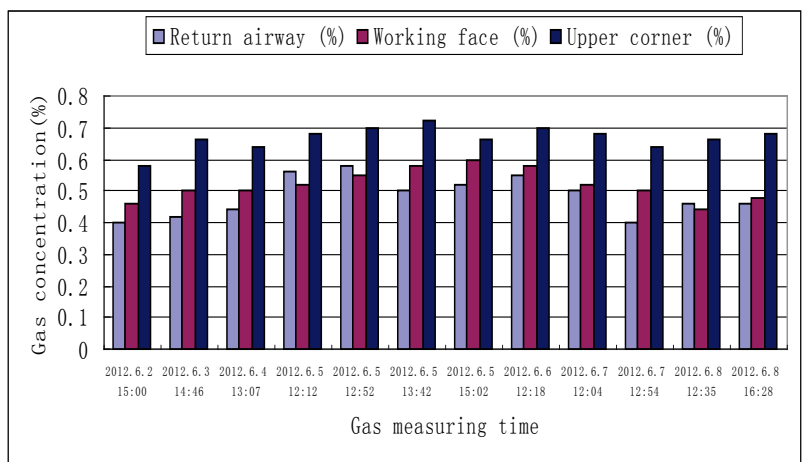

Figure 11 Gas concentration of return airway, working face and upper corner
It can be seen from Fig. 11 that after the implementation of the optimal scheme in No. $32_{2} 12_{(1)}$ working face, the gas concentration of return airway is approximately $0,4 \div 0,5 \%$ in maintenance class, which is obviously a decrease; the gas concentration of mining class is approximately $0,6 \%$, and the maximum value is below $0,7 \%$; the gas concentration of upper corner decreases to $0,6 \div 0,7 \%$, and the maximum value is below $0,8 \%$. Therefore, the improvement of the ventilation pattern in No. $32_{2} 12_{(1)}$ working face ensures the normal production and obviously obtains the gas controlling efficiency.

\section{Conclusion}

From the above analysis, the following conclusions can be drawn:

(1) According to the comparison of numerical simulation experiments of the gas concentration distribution of "one air intake two air return" $U+L$ ventilation pattern and "two air intake one air return" $\mathrm{Y}+\mathrm{L}$ ventilation pattern in Rujigou coal mine, a mixing zone appeared approximately $50 \mathrm{~m}$ from the return airway in the working face using the "two air intake one air return " $\mathrm{Y}+\mathrm{L}$ ventilation pattern, and the average gas concentration of the airflow mixing zone is approximately $1,2 \div 1,6 \%$; the maximum can reach $1,8 \%$. Therefore, 
the $\mathrm{Y}+\mathrm{L}$ ventilation pattern strict the normal production seriously.

(2) Using the orthogonal test method and the numerical simulation method to obtain the stope gas concentration distribution of different schemes, the optimal parameters combination of gas drainage of $\mathrm{U}+\mathrm{L}$ ventilation pattern is determined by combining with the fuzzy optimization evaluation method. The results show that the gas concentration is decreased obviously after the ventilation parameter optimization, the gas concentration in upper corner is approximately $0,7 \div 0,72 \%$, the return airway is approximately $0,6 \div 0,65 \%$, the $\mathrm{L}$ tail roadway is approximately $0,6 \div 0,7 \%$, and the drainage gas concentration of the installation roadway is approximately $1,4 \div 1,7 \%$.

(3) After adopting the optimal scheme of the U+L ventilation pattern of No. $32_{2} 12_{(1)}$ working face in Rujigou coal mine, the gas concentration of mining class decreases to $0,6 \%$, which can ensure the normal production of No. $32_{2} 12_{(1)}$ working face.

\section{Acknowledgments}

This work is financially supported by grants from the National Science Foundation of China (Grant No. 51304203) and the National Natural Sciences Foundation of China (Grant No. 51134023), the authors are grateful for these supports.

\section{References}

[1] Cheng, J. W.; Yang, S. Q. Data mining applications in evaluating mine ventilation system. // Safety Science. 50, 4(2012), pp. 918-922. DOI: 10.1016/j.ssci.2011.08.003

[2] Chen, J. Y.; Fan, X. Q.; Liu, Z. Fluent Based Numerical Analysis of Eliminating Ultra-Limit Gas in Upper Corner by Using Rotary Jet Fan. // Advanced Materials Research. 201-203, (2011), pp. 2212-2215. DOI: 10.4028/www.scientific.net/AMR.201-203.2212

[3] Wu, J. G.; Yang J.; Nobukazu, Nakagoshi; Lu, X. X.; Xu, H. Application of $\mathrm{Y}+\mathrm{L}$ Ventilation to Gas Control on 3303 Mining Face. // Advanced Materials Research. 524-527, (2012), pp. 539-542. DOI: 10.4028/www.scientific.net/AMR.524527.539

[4] Xu, G.; Kray, D. Luxbacher; Saad, Ragab; Steve, Schafrik. Development of a remote analysis method for underground ventilation systems using tracer gas and CFD in a simplified laboratory apparatus. // Tunnelling and Underground Space Technology. 33, (2013), pp. 1-11. DOI: 10.1016/j.tust.2012.09.001

[5] Toraño, J.; Torno, S.; Menéndez, M.; Gent, M. Auxiliary ventilation in mining roadways driven with roadheaders: validated CFD modelling of dust behaviour. // Tunnelling and Underground Space Technology. 26, 1(2011), pp. 201210. DOI: 10.1016/j.tust.2010.07.005

[6] Toraño, J.; Torno, S.; Menendez, M.; Gent, M.; Velasco, J. Models of methane behaviour in auxiliary ventilation of underground coal mining. // International Journal of Coal Geology. $80, \quad 1(2009), \quad$ pp. 35-43. DOl: 10.1016/j.coal.2009.07.008

[7] Yuan, L.; Smith, A. Numerical study on effects of coal properties on spontaneous heating in longwall gob areas. // Fuel. 87, 15-16(2008), pp. 3409-3419. DOl: 10.1016/j.fuel.2008.05.015

[8] Ren, T. X.; Balusu, R. CFD modelling of goaf gas migration to improve the control of spontaneous combustion in longwalls. // In: Coal Operators' Conference. (2005), pp. 259-264.

[9] Huang, J.; Bruining, J.; Wolf, K. H. A. A. Modeling of gas flow and temperature fields in underground coal fires. // Fire Safety Journal. 36, 5(2001), pp. 477-489. DOI: 10.1016/S0379-7112(01)00003-0

[10] Heerden, J. V.; Sullivan, P. The application of CFD for evaluation of dust suppression and auxiliary ventilating systems used with continuous miners. // In: Proceedings of the 6th U.S. Mine Ventilation Symposium, Littleton, USA, (1993), pp. 293-297.

[11] Wang, P.; Feng, T.; Liu, R., Numerical simulation of dust distribution at a fully mechanized face under the isolation effect of an air curtain. // Mining Science and Technology. 21, (2011), pp. 65-69.

[12] Wu, S. Y.; Guo, Y. Gas control of mechanical mining coal face of high yield using $\mathrm{Y}$ model ventilation manner. // Journal of XI'AN University of Science \& Technology. 21, 3(2001), pp. 205-207.

[13] Li, Z.; Ti Z.; Zhao, G. Numerical simulation of gas emission in goaf of robbing working surface. // The Chinese Journal of Geological Hazard and Control. 16 , 4(2005), pp. 42-46.

[14] Li, Z. X.; Hai, G. Z.; Qin, S. Y. Numerical simulation and visual display of air flow pattern in goaf. // Journal of China Coal Society. 26, 1(2001), pp. 76-801.

[15] Li, Z. X.; Sun, G. Y.; Qin, S. Y. The study on the Numerical Simulation and determination of parameters in gas control at the upper corner in U-pattern ventilation face. // The Chinese Journal of Geological Hazard and Control. 12, 4(2001), pp. 9-12.

[16] Wang, K.; Jiang, S. G.; Zhang, W. Q. Numerical simulation of tail roadway change to gas flow field in goaf. // Journal of Mining \& Safety Engineering. 29, 1(2012), pp. 124-130.

[17] Wang, K.; Wu, W. Y. Numerical simulation of flow field and gas transportation in goaf of fully mechanized sub-level caving face with J-shape ventilation system. // Journal of China University of Mining \& Technology. 36, 3(2007), pp. 277-282. DOI: 10.1016/S1006-1266(07)60088-1

[18] Cheng Y. P. The discussion of air distribution between major and accessory air intake entries at the fully mechanized Y-shaped working face with high gas concentration. // Safety in Coal Mines. 2, (1990), pp. 32-35.

\section{Authors' addresses}

\section{He Shao, postgraduate}

China University of Mining and Technology

School of Safety Engineering, China University of Mining and Technology, Xuzhou District, Jiangsu Province, P. R. China ZIP code: 221116

E-mail: 50605151@qq.com

Kai-yan Chen, Ph.D., Professor, corresponding author China University of Mining and Technology

School of Safety Engineering, China University of Mining and Technology, Xuzhou District, Jiangsu Province, P. R. China ZIP code: 221116

E-mail: kychen109@126.com

Hong-mei Zhao, postgraduate

China University of Mining and Technology

School of Safety Engineering, China University of Mining and Technology, Xuzhou District, Jiangsu Province, P. R. China ZIP code: 221116

E-mail: 41762848@qq.com

\section{Ming-ming $\mathbf{L i}$}

Department of Mining Engineering, West Virginia University, Morgantown, WV 26505, USA

E-mail: limingming.lmm@gmail.com 